\title{
Dose-dependent effect of chronic exposure to lead acetate on the dynamics of the content of delta-aminolevulinic acid and essential trace elements in the serum of laying hens
}

\author{
E. Dotsenko*, A. Paliy****, D. Morozenko***, R. Dotsenko***, A. Zemlianskyi***, O. Pavlichenko** \\ *Institute of Experimental and Clinical Veterinary Medicine, Kharkiv, Ukraine \\ **State Biotechnological University, Kharkiv, Ukraine \\ ***National University of Pharmacy, Kharkiv, Ukraine
}

Article info

Received 06.10.2021

Received in revised form 30.10.2021

Accepted 01.11.202

Institute of Experimental and Clinical Veterinary Medicine, Pushkinska st., 83,

Kharkiv, 61023, Ukraine

Tel.: + 38-068-262-44-37.

E-mail:

dotsenkokate178@gmail.com

State Biotechnological University

Alchevskyh st., 44

Kharkiv, 61002, Ukraine

Tel.: +38-050-026-35-30.

E-mail:

pavlichenkoelena777@gmail.com

National University of Pharmacy,

Pushkinska st., 53,

Kharkiv, 61002, Ukraine

Tel.: +38-050-889-70-49.

E-mail:romdtox@ukr.net

Dotsenko, E., Paliy, A., Morozenko, D., Dotsenko, R., Zemlianskyi, A., \& Pavlichenko, O. (2021). Dose-dependent effect of chronic exposure to lead acetate on the dynamics of the content of delta-aminolevulinic acid and essential trace elements in the serum of laying hens. Regulatory Mechanisms in Biosystems, 12(4), 689-695. doi:10.15421/022195

One of the most global and dangerous pollutants is considered to be lead, due to its ability to accumulate in living organisms, to be included in the metabolic cycle, to form highly toxic organometallic compounds, not being biodegradable. To study the chronic effects of lead acetate, an experiment was performed on laying hens of Lohmann Brown cross. For research, one control and three experimental groups were formed, 20 chickens in each. Birds of the experimental groups were administered lead acetate daily with compound feed in doses (in terms of metal): Group I - $50 \mathrm{mg} / \mathrm{kg}$ of feed, II $-75 \mathrm{mg} / \mathrm{kg}$ of feed, III $-150 \mathrm{mg} / \mathrm{kg}$ of feed. Access to water was not restricted. The birds of the control group received a complete diet without lead acetate. On the 30th, 90th, 120th days of the experiment and the 20th day after withdrawal of the toxicant (the 140th day of the experiment), we took blood samples from birds for biochemical and toxicological studies. The concentration of delta-aminolevulinic acid ( $\delta$-ALA) in the serum of laying hens was determined by reversed-phase high-performance liquid chromatography. Determination of the content of lead in the serum of laying hens was performed by X-ray fluorescence analysis. The concentration of total calcium, inorganic phosphorus, and magnesium in the serum of the laying hens was determined using production kits. We detected the dose-dependent chronic effect of lead acetate on the dynamics of the content of delta-aminolevulinic acid and essential trace elements in the serum of laying hens. The administration of lead acetate into the body of productive poultry for 120 days in doses of 50,75 , and $150 \mathrm{mg} / \mathrm{kg}$ with feed did not cause visible clinical signs of poisoning, but caused a violation of porphyrin metabolism, manifested in a reliable increase in the concentration of delta-aminolevulinic acid in serum on the 30th, 90th and 120th days of the experiment. It has been experimentally proven that the administration into the body of laying hens of lead acetate in doses of 50,75 and $150 \mathrm{mg} / \mathrm{kg}$ of feed for 120 days leads to the maximum accumulation of lead in the serum on the 30th, 90th, and 120th days of the experiment. Prolonged administration of lead acetate to laying hens at high concentrations is characterized by a reliable decrease in the content of total calcium, inorganic phosphorus and magnesium in the serum of laying hens and a reliable increase in the content of ferrum. In the future it is necessary to study the intensity of lipid peroxidation processes in laying hens under chronic exposure to lead acetate.

Keywords: heavy metals; amino acid; biomarkers; toxicodynamics; microelements; poultry.

\section{Introduction}

According to the World Health Organization, lead is accepted as one of the most global and dangerous pollutants. The real threat of pollution of the biosphere by this xenobiotic is due to its stability, solubility in precipitation, the ability to be sorbed by soil, plants, bottom sediments, which leads to the gradual accumulation of lead in the environment (Adeyemo et al., 2010; Pourrut et al., 2011; Silva-Sánchez et al., 2015). The main sources of pollution of agro-ecosystems by lead compounds are emissions from industrial enterprises, quarries, mines, thermal power plants, fuel combustion products, battery production, use of metal-containing pesticides, phosphorus-containing fertilizers and chemicals for crop protection (Rucińska-Sobkowiak, 2016). Agrochemicals, by changing the acid-alkali properties, affect the intensity of bioaccumulation and transformation of lead in the upper soil layers (Clark \& Knudsen, 2013; Fillion et al., 2014).

According to the results of monitoring studies (Clemens \& Ma, 2016; Amin et al., 2018), an increased content of mobile forms of lead in agricultural soils and grain crops has been determined. Based on the data of the authors (Puschenreiter et al., 2005; Tangahu et al., 2011; Shulman et al.,
2017; Kozak \& Brygadyrenko, 2018; Souri et al., 2019), the accumulation of this xenobiotic in certain parts of the trophic chain "atmospheric air water - soil - plants - feed - livestock products" is possible. It has been established that the systematic administration of lead by the alimentary way in low concentrations poses a potential danger to the body of poultry, leads to accumulation of metal in organs and tissues, as a consequence, disrupts physiological and biochemical processes at the cellular level, causes chronic intoxication and reduces egg production (Ebrahimi et al., 2015; Mordarski et al., 2018). Data from literature sources indicate an increase in cases of contamination of poultry products with heavy metal compounds (Roegner et al., 2013; Bautista et al., 2014). The production of environmentally friendly livestock products requires the implementation of comprehensive approaches to minimize and prevent the presence of hazardous compounds and their metabolites in both feed and final food products (Rodionova et al., 2020).

To date, the mechanisms of toxic effects of lead in the body of laying hens of highly productive crosses have not been studied enough. Therefore, studies aimed at finding criteria for early diagnosis of chronic poisoning of productive poultry with lead compounds are relevant. 
Numerous current studies are devoted to the mechanisms of toxic effects of lead ions on animals and birds (Kim et al., 2019; Oladipo et al., 2020). The special danger of the ecotoxicant is explained by its ability to be accumulated in living organisms, to be included in a metabolic cycle, to form highly toxic organometallic compounds not being subjected to biological decomposition. According to the literature (Ray, 2016; Debnath et al., 2019), the toxic effects of lead are characterized by lesions of the blood system, disorders of porphyrin metabolism, damage to the cardiovascular and nervous systems. The features and mechanism of action of lead are widely covered, mainly at the level of lethal doses, but this information is insufficient to predict the consequences of chronic effects of low doses of lead on the macroorganism (Boskabady et al., 2018).

It is almost impossible to clinically diagnose the initial stage of chronic poisoning of productive poultry with lead compounds, therefore studies to search the biochemical criteria for early diagnosis of poisoning become relevant. The most informative indicator that allows timely detection of latent signs of metabolic disorders in the conditions of lead-induced toxicosis is delta-aminolevulinic acid, an intermediate product of heme biosynthesis (Sakai, 2000). It should be noted that the accumulation of intermediates of heme biosynthesis in biological fluids is one of the main criteria for laboratory diagnosis of animal and poultry poisoning by heavy metal compounds (Dehari-Zeka et al., 2020). Also, the determination of the content of macro-and microelements in the serum of poultry in chronic lead-induced toxicosis is of clinical and diagnostic importance (Dobrakowski et al., 2017).

Today, trace elements are known to have bioantagonistic properties against lead, including calcium, ferrum, zinc, and others. It is scientifically substantiated that the mechanism of toxic action of lead ions is its ability to interact with sulfhydryl, carboxyl and amine groups of enzymes, inhibit their activity and competitively replace bivalent $\left(\mathrm{Ca}^{2+}, \mathrm{Mg}^{2+}, \mathrm{Fe}^{2+}\right)$ and monovalent $\left(\mathrm{Na}^{+}\right)$cations, to which lead has a high affinity (Rădulescu \& Lundgren, 2019).

The ability of lead to replace calcium from specific ligand binding sites and disrupt its passive transport has been established (Jadoon \& Malik, 2017). Lead, as a competitive biometal in relation to calcium, can displace it from the sites of binding to phosphate ligands in tissues, disrupt passive transport across membranes, realizing its damaging effect (Andjelkovic, 2019).

Literature data indicate the role of calcium in the absorption of lead (Kopic \& Geibel, 2013; Assi et al., 2016). Research of Manghat et al. (2014) has shown that lead, under conditions of chronic low-dose loading, causes violation of calcium-phosphorus homeostasis and oxidative metabolism of cells due to changes in intracellular flow of calcium and phosphorus, their replacement at specific receptors with subsequent activation of calcium-dependent enzymes. According to Vorvolakos et al. (2016), Hussain et al. (2020) and Choi et al. (2021) under conditions of increasing the content of lead in the blood above the reference level, there is a reliable decrease in the concentration of total calcium in the serum of experimental animals. It has been scientifically proven that calcium and lead are distributed, deposited and metabolized almost identically, and the removal of lead from the bones is possible by reducing the calcium content in the blood (Wani et al., 2015). However, in the literature there are almost no data on the early diagnosis of chronic poisoning of birds of highly productive crosses by lead compounds. The dose-dependent effect of lead acetate on the state of mineral metabolism, in particular, on the content of total calcium, inorganic phosphorus, magnesium and ferrum in the serum of laying hens, also remains insufficiently studied. Therefore, it is necessary to experimentally substantiate the methods of early diagnosis based on the study of biochemical parameters of the serum of laying hens under the conditions of experimentally induced chronic alimentary toxicosis.

Given the urgency of the problem, we studied the dose-dependent effect of chronic exposure to lead acetate on the dynamics of delta-aminolevulinic acid and essential trace elements in the serum of laying hens.

\section{Materials and methods}

Experimental studies were conducted on the basis of specialized laboratories of the National Scientific Center "Institute of Experimental and Clinical Veterinary Medicine". The animal experiments did not contra- vene the current legislation of Ukraine (Article 26 of the Law of Ukraine No. 5456-VI of 16.10.2012 "On protection of animals from cruel treatment") and "General ethical principles of animal experiments", adopted by the First National Congress of Bioethics (Kyiv, 2001) and international bioethical standards (materials of the IV European Convention for the Protection of Vertebrate Animals Used for Experimental and Other Purposes, Strasbourg, 1985) (Simmonds, 2017). The research program was reviewed and approved by the Bioethics Commission of the National Scientific Center "Institute of Experimental and Clinical Veterinary Medicine" in the current order.

An experiment to study the chronic effects of lead acetate was performed on chickens of the highly productive cross Lohmann Brown ( $\mathrm{n}=$ 80 ), aged 265 days, body weight $1.7-2.1 \mathrm{~kg}$, productivity $98 \%$. Experimental animals were kept in standard vivarium conditions in cages at a temperature of $18.0 \pm 2.0{ }^{\circ} \mathrm{C}$, relative humidity of $60 \%$, lighting regime 12-hour day-night, which corresponded to existing standards. The birds of the control and experimental groups were fed a complete ration of combined feed of good quality, which corresponded to the age and productivity, in accordance with the approved technological standards for poultry. Laying hens were kept in cages for 14 days for adaptation. Prior to the experiment, the animals were weighed and labeled.

For research, one control and three experimental groups were formed, 20 chickens in each. Birds of the experimental groups were administered lead acetate daily with compound feed in doses (in terms of metal): Group I $-50 \mathrm{mg} / \mathrm{kg}$ of feed, II $-75 \mathrm{mg} / \mathrm{kg}$ of feed, III $-150 \mathrm{mg} / \mathrm{kg}$ of feed. Access to water was not restricted. The birds of the control group were fed a complete ration without acetate lead. Assessment of the general clinical condition and productivity of laying hens was performed daily once a day. The total duration of the chronic experiment was 140 days.

For the experimental studies we used lead acetate $\mathrm{Pb}\left(\mathrm{CH}_{3} \mathrm{COOH}\right)$ $3 \mathrm{H}_{2} \mathrm{O}$, qualification "chemically pure", (Merck, Germany) in accordance with current regulations.

On the 30th, 90th, 120th days of the experiment and the 20th day after the toxicant withdrawal (the 140th day of the experiment), we took blood samples from birds for biochemical and toxicological studies. Blood from laying hens was collected intravitally from the axillary vein on an empty stomach using "Vacuette" vacuum tubes (Greiner, Austria). Serum was obtained by centrifugation for 20 minutes at $3000 \mathrm{rpm}$. Aliquots of serum were poured into Eppendorf-type tubes for storage at minus $20^{\circ} \mathrm{C}$ until use in studies.

The concentration of delta-aminolevulinic acid ( $\delta$-ALA) in the serum of laying hens was determined by reversed-phase high performance liquid chromatography on a chromatograph LC 20 Prominence Shimadzu (Japan). Chromatography conditions: steel column "Reprosil Pur Aqua" $\mathrm{C} 18$ $150 \times 2.0 \mathrm{~mm}, 3.0 \mu \mathrm{m}$, eluent: phosphate buffer-acetonitrile, mobile phase velocity $0.4 \mathrm{~cm}^{3} / \mathrm{min}$, column thermostat temperature $50{ }^{\circ} \mathrm{C}$, detection wavelength $360 \mathrm{~nm}$. The matrix is the blood serum of laying hens.

Determination of the content of lead in the serum of laying hens was performed by X-ray fluorescence analysis on the device "SpectroscanMax" (Russia). The total calcium content was determined with Arsenazo III complexone. Calcium in the sample reacts with Arsenazo III, forming a coloured complex, which was measured spectrophotometrically. Determination of the concentration of inorganic phosphorus (as phosphate) in the serum was performed using molybdic acid. The concentration of ferrum was determined by spectrophotometric method. Ferrum is released from serum ferrum-binding peptides and reduced by guanidine and hydroxylamine. The sodium salt 3-(2-pyridyl)-5,6-bis-(4-sulfophenyl)-1,2,4triazine(ferrosine) forms a purple complex with $\mathrm{Fe}^{+2}$ ions, which was determined colorimetrically. Serum magnesium concentration was determined with xylidyl blue in alkaline medium. The intensity of the formed coloured complex was measured at a wavelength of $520 \mathrm{~nm}$.

The results of biochemical studies are presented in accordance with the International System of Units, recommended for use in clinical laboratory practice, and processed using the computer program Statistica 10.0 (StatSoft Inc., USA). The obtained results were processed by standard methods of variation statistics using non-parametric and parametric criteria. Numerical data were processed using one-way analysis of variance (ANOVA). In the case of parametric distribution, the quantitative characteristics of signs were presented in the form of arithmetic sampling and 
standard deviation $(\mathrm{x} \pm \mathrm{SD})$. Differences between samples were considered reliable at $\mathrm{P}<0.05$. Comparison of three or more groups the quantitative sign with the correct distribution of values was carried out using the Tukey test for subsequent pairwise comparisons of groups, taking into account the Bonferroni correction. The coefficient of determination $\mathrm{R}^{2}$ was calculated by the formula $\mathrm{R}^{2}=\mathrm{rxy}^{2}$.

\section{Results}

The research showed that the administration of lead acetate in doses of 50,75 and $150 \mathrm{mg} / \mathrm{kg}$ for 120 days with diet of laying hens did not cause visible clinical signs of poultry poisoning, but led to disruption of porphyrin metabolism, in particular, increased content of deltaaminolevulinic acid, an intermediate product of heme biosynthesis, in the serum of laying hens. On the 30th day of the experiment, the activity of delta-aminolevulinic acid was reliably higher compared with the control in chickens receiving the toxicant at doses of 75 and $150 \mathrm{mg} / \mathrm{kg}$ of feed by $4.8 \%$ and $14.6 \%$, respectively (Fig. 1).

In poultry which received lead acetate at a dose of $50 \mathrm{mg} / \mathrm{kg}$ of feed, the indicators did not differ significantly from the control. On the 90th day, chickens of I, II and III experimental groups showed a reliable increase in the concentration of ALA by $7.9 \%, 16.1 \%$ and $39.9 \%(\mathrm{P}<0.001)$, respectively. On the 120th day, a reliable increase in the content of ALA in chickens of all experimental groups by $26.6 \%, 48.3 \%$ and $133.6 \%$, respectively, was established, compared with the control group. 20 days after xenobiotic administration toxicant withdrawal, the ALA content remained reliably $(\mathrm{P}<0.001)$ higher than the control in poultry of I, II and III experimental groups by $7.4 \%, 28.8 \%$ and $39.7 \%$, respectively.

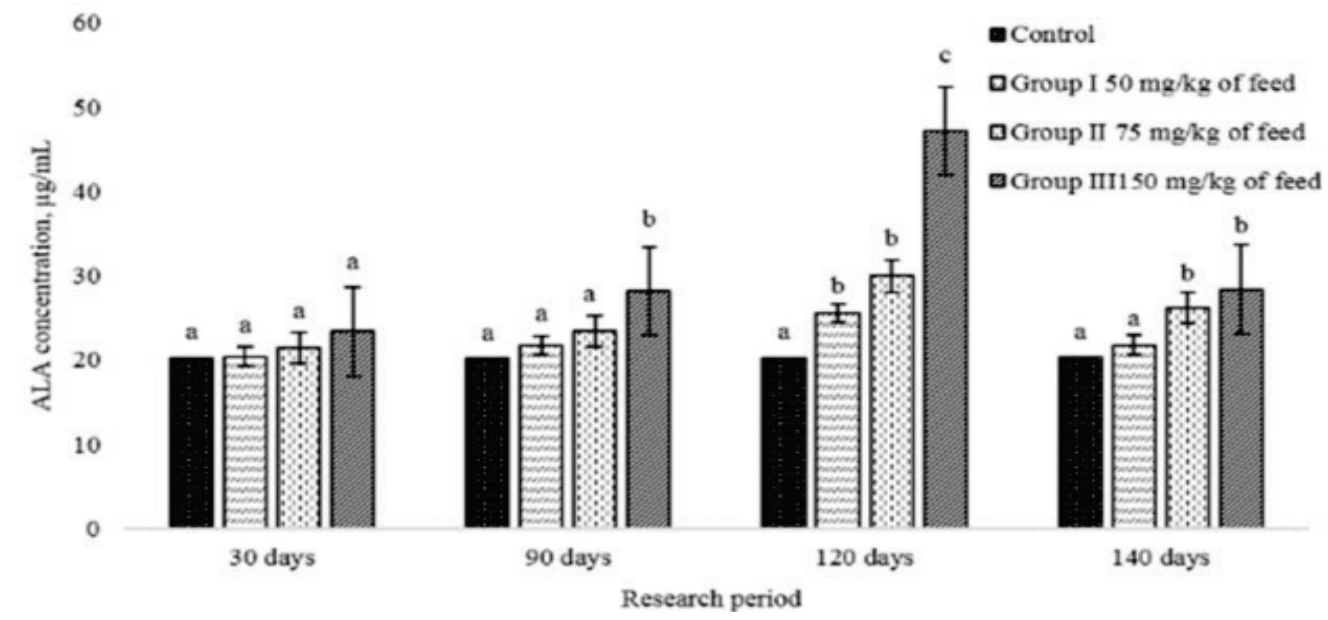

Fig. 1. The activity of delta-aminolevulinic acid in the serum of laying hens under the influence of lead acetate in chronic experiment $(x \pm S D, n=5)$

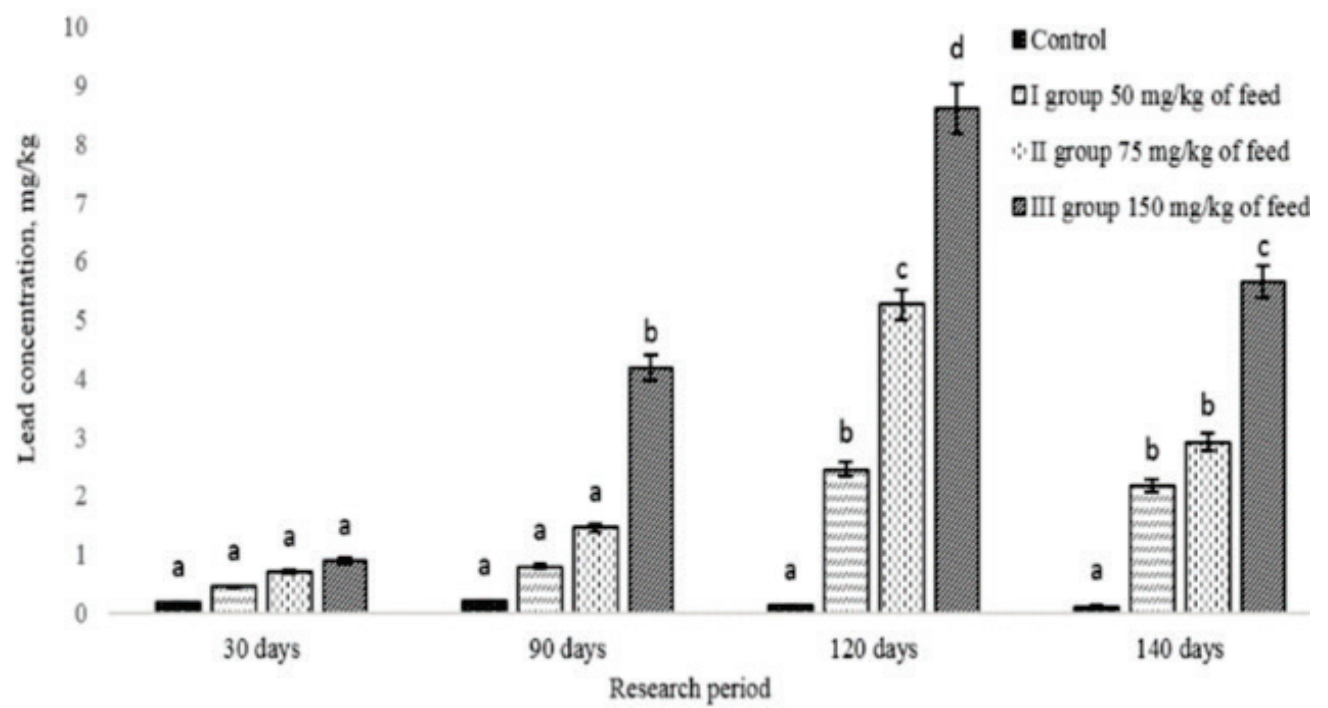

Fig. 2. The dynamics of the content of lead in the serum of laying hens under the influence of lead acetate in a chronic experiment $(x \pm S D, n=5)$

According to the obtained data (Fig. 2), on the 30th day of the experiment, a reliable increase in the lead content was established, compared with the control indicator, in the blood of chickens of groups I, II and III by $2.5,3.9$ and 5.0 times, respectively. On the 90th and 120th day, the concentration of the element in the blood of chickens of all experimental groups remained reliably higher than the control values by $3.6,6.6$, and 19.0, and 18.9, 40.5, and 66.2 times, respectively. After withdrawal of the toxicant, the content of lead in the blood exceeded the control by 18.2 , 24.3 and 47.2 times, respectively. A graphical representation of the relationship between the content of lead and the concentration of deltaaminolevulinic acid in the serum of poultry that received the toxicant at a dose of $150 \mathrm{mg} / \mathrm{kg}$ of feed for 90 days is shown in Figure 3. A direct positive correlation between indicators has been established. Studying the dynamics of the content of total calcium in the serum, it has been found that on the 30th day in the birds of I, II and III experimental groups the indicator was reliably lower than the control by $10.8 \%, 22.8 \%$, and $35.2 \%$, respectively (Table 1 ).

On the 90th and 120th days of the experiment, the dynamics of total calcium content were as follows: the indicator remained reliably lower (P $<0.001$ ) than control by $26.9 \%, 40.7 \%$, and $48.2 \%$ and $14.0 \%, 25.4 \%$, and $62.4 \%$, respectively. On the 20th day after withdrawal of lead acetate, the level of total calcium remained reliably lower in all experimental groups, compared with the control group, by $8.6 \%, 19.5 \%$, and $48.8 \%(\mathrm{P}<0.001)$.

Studying the dynamics of the content of inorganic phosphorus in the blood serum of chickens, it has been found that on the 30th day in the birds of the experimental group I the indicator was reliably lower than the control values by $5.5 \%, 14.8 \%$, and $51.1 \%$, respectively. On the 90 th day, a reliable decrease in the phosphorus content in all experimental groups 
was established by $41.1 \%, 53.5 \%$, and $64.8 \%$, respectively. On the 120 th day of the experiment, the phosphorus content in poultry of experimental groups I, II and III was reliably (P $<0.001)$ lower by $42.5 \%, 48.2 \%$, and $73.6 \%$. 20 days after withdrawal of the xenobiotic, the phosphorus level was reliably lower than the control in all experimental groups by $17.8 \%$, $26.2 \%$, and $40.6 \%(\mathrm{P}<0.001)$.

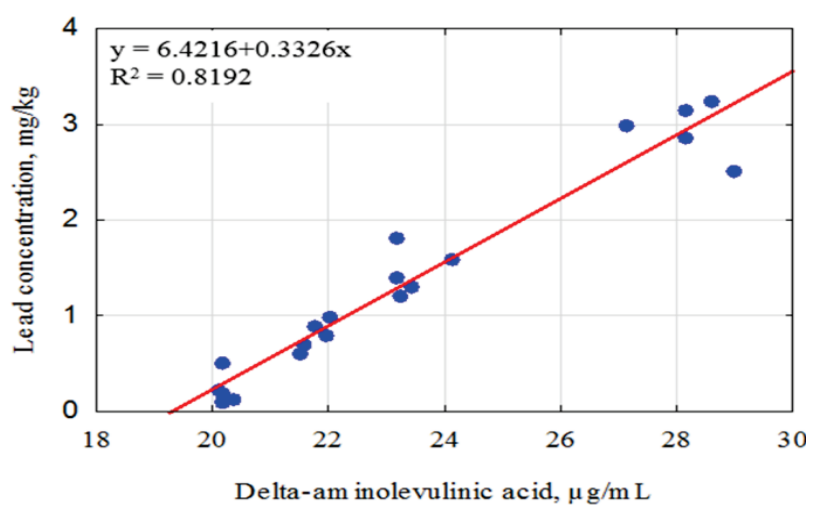

Fig. 3. The relationship between the content of lead and the concentration of delta-aminolevulinic acid in the serum of laying hens on the 90th day of the experiment (coefficient of multiple determination R2 $-0.8192, \mathrm{n}=20$ )

The dynamics of the content of total magnesium in the serum of poultry was as follows: on the 30th day in poultry of the experimental groups I, II and III the indicator was reliably lower than the control by $29.3 \%$,
$46.7 \%$, and $59.8 \%$, respectively. On the 90 th and 120 th days, the magnesium level remained reliably lower $(\mathrm{P}<0.001)$ than control by $20.6 \%$, $39.7 \%$, and $48.5 \%$ and $27.7 \%, 49.4 \%$, and $77.1 \%$, respectively. On the 20th day after withdrawal of lead acetate, the concentration of magnesium was reliably lower than the control values in all experimental groups by $20.7 \%, 39.1 \%$, and $59.8 \%$, respectively $(\mathrm{P}<0.001)$.

When determining the concentration of ferrum in the serum of chickens of the experimental group I on the 30th day we recorded a reliable decrease in the content of trace elements by $11.5 \%$. In poultry of experimental groups II and III we found a reliable $(\mathrm{P}<0.001)$ decrease in ferrum by $16.8 \%$ and $22.3 \%$, compared with the values in the control. On the 90th and 120th days in chickens of experimental groups I, II and III this indicator was higher by $38.3 \%, 86.3 \%$, and $116.8 \%$ and $48.6 \%, 111.2 \%$ and $169.6 \%$, respectively. On the 20th day after cessation of chronic exposure to lead acetate, the ferrum content in the serum of chickens of experimental groups I, II and III remained higher than the control values by $19.5 \%, 32.2 \%$, and $100.7 \%(\mathrm{P}<0.001)$, respectively.

The point graph and the linear trend of the relationship between the content of lead and the concentration of total calcium in the serum of laying hens on the 90th day of the experiment (Fig. 4) is presented.

The relationship between the content of lead and the concentration of inorganic phosphorus in the serum of poultry on the 90th day of the experiment (Fig. 5) has been established. As a result of correlation-regression analysis of the data, a moderate correlation between the indicators was established. The data obtained indicate that the reliable $(\mathrm{P}<0.001)$ decrease in the level of inorganic phosphorus in the serum is associated with prolonged administration of lead acetate with feed.

Table 1

Dynamics of mineral metabolism parameters in laying hens under the influence of lead acetate in a chronic experiment $(x \pm S E, n=5)$

\begin{tabular}{|c|c|c|c|c|c|}
\hline \multirow{2}{*}{ Parameter } & \multirow{2}{*}{ Groups } & \multicolumn{4}{|c|}{ Research period } \\
\hline & & 30 days & 90 days & 120 days & 140 days \\
\hline \multirow{4}{*}{$\begin{array}{l}\text { Total calcium, } \\
\mathrm{mmol} / \mathrm{mL}\end{array}$} & Control & $6.31 \pm 0.49^{\mathrm{a}}$ & $6.04 \pm 0.39^{\mathrm{a}}$ & $6.07 \pm 0.16^{\mathrm{a}}$ & $6.05 \pm 0.16^{\mathrm{a}}$ \\
\hline & $50 \mathrm{mg} / \mathrm{kg}$ of feed & $5.63 \pm 0.31^{\mathrm{a}}$ & $4.41 \pm 0.71^{b}$ & $5.22 \pm 0.12^{\mathrm{a}}$ & $5.53 \pm 0.29^{\mathrm{a}}$ \\
\hline & $75 \mathrm{mg} / \mathrm{kg}$ of feed & $4.87 \pm 0.42^{\mathrm{a}}$ & $3.58 \pm 0.42^{\mathrm{b}}$ & $4.53 \pm 0.55^{\mathrm{a}}$ & $4.87 \pm 0.19^{\mathrm{a}}$ \\
\hline & $150 \mathrm{mg} / \mathrm{kg}$ of feed & $4.09 \pm 0.08^{\mathrm{a}}$ & $3.13 \pm 0.09^{b}$ & $2.28 \pm 0.40^{\mathrm{c}}$ & $3.10 \pm 0.07^{b}$ \\
\hline \multirow{4}{*}{$\begin{array}{l}\text { Total phosphorus, } \\
\mathrm{mmol} / \mathrm{mL}\end{array}$} & Control & $1.82 \pm 0.03^{\mathrm{a}}$ & $1.85 \pm 0.09^{\mathrm{a}}$ & $1.93 \pm 0.07^{\mathrm{a}}$ & $2.02 \pm 0.06^{b}$ \\
\hline & $50 \mathrm{mg} / \mathrm{kg}$ of feed & $1,72 \pm 0,04^{\mathrm{a}}$ & $1.09 \pm 0.04^{\mathrm{b}}$ & $1.11 \pm 0.06^{\mathrm{b}}$ & $1.66 \pm 0.14^{\mathrm{a}}$ \\
\hline & $75 \mathrm{mg} / \mathrm{kg}$ of feed & $1.55 \pm 0.10^{\mathrm{a}}$ & $0.86 \pm 0.12^{\mathrm{b}}$ & $1.00 \pm 0.14^{\mathrm{a}}$ & $1.49 \pm 0.21^{\mathrm{a}}$ \\
\hline & $150 \mathrm{mg} / \mathrm{kg}$ of feed & $0.89 \pm 0.08^{\mathrm{a}}$ & $0.65 \pm 0.04^{\mathrm{b}}$ & $0.51 \pm 0.08^{b}$ & $1.20 \pm 0.12^{\mathrm{c}}$ \\
\hline \multirow{4}{*}{$\begin{array}{l}\text { Total magnesium, } \\
\mathrm{mmol} / \mathrm{mL}\end{array}$} & Control & $0.92 \pm 0.05^{\mathrm{a}}$ & $0.68 \pm 0.07^{b}$ & $0.83 \pm 0.15^{\mathrm{a}}$ & $0.87 \pm 0.09^{\mathrm{a}}$ \\
\hline & $50 \mathrm{mg} / \mathrm{kg}$ of feed & $0.65 \pm 0.05^{\mathrm{a}}$ & $0.54 \pm 0.03^{b}$ & $0.60 \pm 0.06^{\mathrm{a}}$ & $0.69 \pm 0.06^{\mathrm{a}}$ \\
\hline & $75 \mathrm{mg} / \mathrm{kg}$ of feed & $0.49 \pm 0.04^{\mathrm{a}}$ & $0.41 \pm 0.04^{\mathrm{a}}$ & $0.42 \pm 0.05^{\mathrm{a}}$ & $0.53 \pm 0.04^{b}$ \\
\hline & $150 \mathrm{mg} / \mathrm{kg}$ of feed & $0.37 \pm 0.04^{\mathrm{a}}$ & $0.35 \pm 0.05^{\mathrm{a}}$ & $0.19 \pm 0.02^{\mathrm{b}}$ & $0.35 \pm 0.06^{\mathrm{a}}$ \\
\hline \multirow{4}{*}{$\begin{array}{l}\text { Iron, } \\
\mu \mathrm{mol} / \mathrm{L}\end{array}$} & Control & $10.08 \pm 0.44^{\mathrm{a}}$ & $9.37 \pm 0.50^{b}$ & $9.88 \pm 0.12^{b}$ & $9.17 \pm 0.58^{\mathrm{c}}$ \\
\hline & $50 \mathrm{mg} / \mathrm{kg}$ of feed & $8.92 \pm 0.35^{\mathrm{a}}$ & $12.96 \pm 1.26^{\mathrm{b}}$ & $14.68 \pm 1.43^{b}$ & $10.96 \pm 1.35^{\mathrm{c}}$ \\
\hline & $75 \mathrm{mg} / \mathrm{kg}$ of feed & $8.39 \pm 0.16^{\mathrm{a}}$ & $17.46 \pm 2.93^{b}$ & $20.87 \pm 2.96^{b}$ & $12.12 \pm 0.42^{\mathrm{c}}$ \\
\hline & $150 \mathrm{mg} / \mathrm{kg}$ of feed & $7.83 \pm 0.29^{\mathrm{a}}$ & $20.31 \pm 0.88^{b}$ & $26.64 \pm 0.53^{b}$ & $18.41 \pm 0.61^{\mathrm{c}}$ \\
\hline
\end{tabular}

Note: different letters indicate the values significantly differing one from another within one line of the Tablel on the results of comparison using the Tukey test $(\mathrm{P}<0.05)$ with Bonferroni correction.

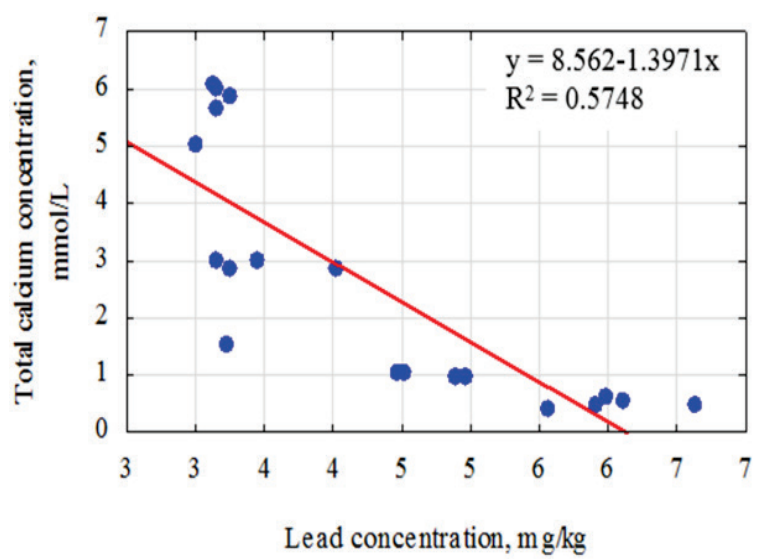

Fig. 4. Graph of the relationship between the content of lead and the concentration of total calcium in the serum of laying hens on the 90 th day of the experiment $(n=20)$

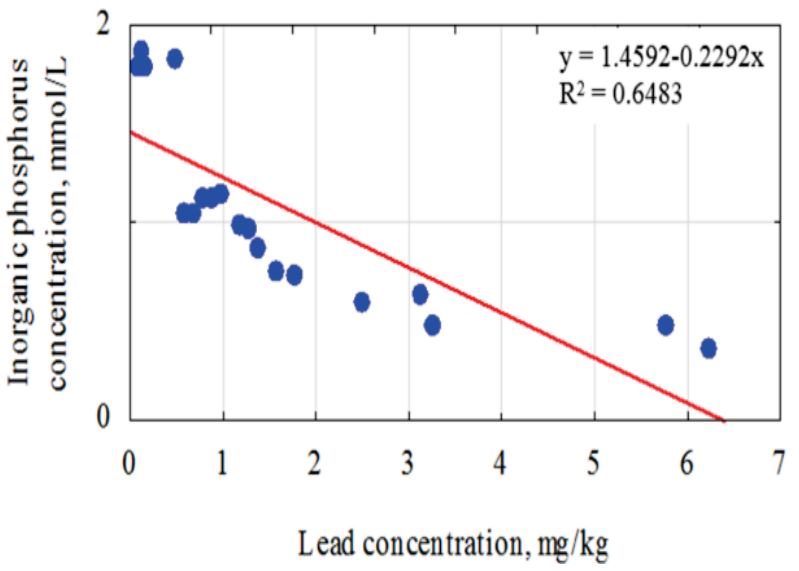

Fig. 5. Graph of the relationship between the content of lead and the concentration of inorganic phosphorus in the serum of laying hens on the 90th day of the experiment $(\mathrm{n}=20)$ 
A correlation was found between the lead content and the concentration of ferrum in the serum of laying hens on the 90th day of the chronic experiment (Fig. 6).

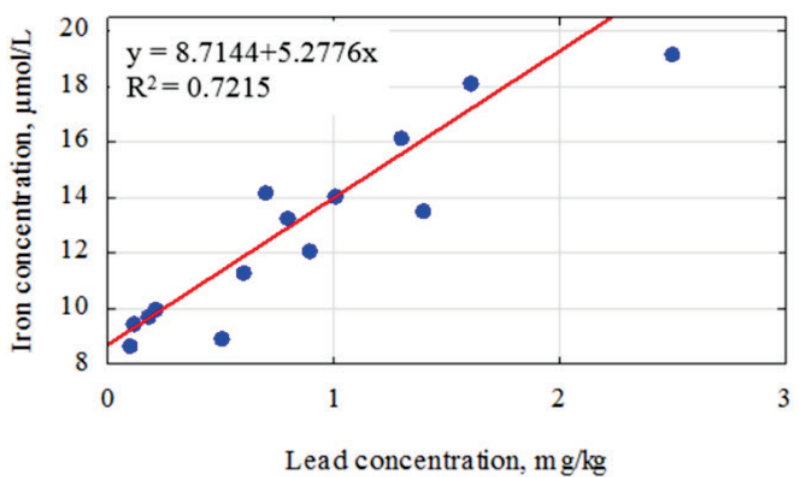

Fig. 6. Graph of the relationship between the content of lead and the concentration of iron $n$ the serum of laying hens on the 90th day of the experiment $(\mathrm{n}=20)$

Correlations between lead content and magnesium concentration in serum of laying hens were established on the 90th day of the experiment. According to the linear regression data, an inverse relationship was found between the indicators (Fig. 7).

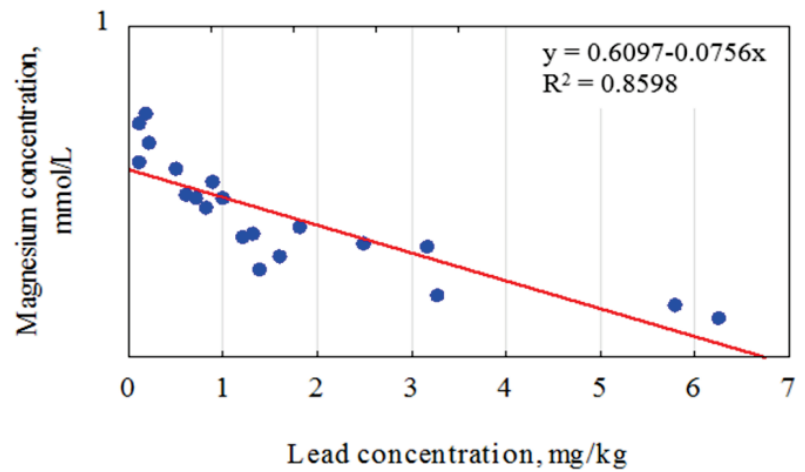

Fig. 7. Graph of the relationship between the content of lead and the concentration of magnesium in the serum of laying hens on the 90th day of the experiment $(n=20)$

\section{Discussion}

Blood as one of the body's biological fluids responds by qualitative and quantitative changes in the composition to any exogenous effects, as a consequence, is a kind of biomarker that allows you to determine the general condition of organs and systems and assess the course of major metabolic processes (Warne et al., 2015; Dehari-Zeka et al., 2020). That is why the study of biochemical parameters of animal blood is one of the informative methods (Orobchenko et al., 2020; Zaitsev et al., 2020). The need to study the effects of xenobiotics on the body of productive poultry is caused by the significant distribution of heavy metals in the environment, their stability, high ability to accumulate in the biosphere, ease of inclusion in the main food chains and the risk of accumulation in the body in large quantities (Rodionova et al., 2020; Soumaoro et al., 2021).

In the modern literature, the features, nature and mechanism of action of heavy metals are widely covered, mainly at the level of average lethal doses, but this information is insufficient to predict the effects of chronic exposure at subthreshold doses (Amin et al., 2018). In recent years, scientists have focused on in-depth study of the mechanisms of toxic effects of heavy metals, however, the peculiarities of the metabolism of lead in the body of poultry are currently insufficiently studied. Therefore, it was necessary to conduct toxicological studies on laying hens. The analysis of the obtained results showed that the long-term administration of lead acetate in doses of 50,75 and $150 \mathrm{mg} / \mathrm{kg}$ of feed to the bird did not cause visible clinical signs of poisoning, but caused a violation of porphyrin metabolism. The leading link in the pathogenesis of chronic heavy metal poiso- ning is a violation of porphyrin metabolism and heme biosynthesis. According to the literature, exposure to lead ions for a long time in doses below the $\mathrm{LD}_{50}$, leads to a significant inhibition of the activity of enzymes involved in heme biosynthesis, in particular, delta-aminolevulinic acid dehydrate. As a result, the concentration of delta-aminolevulinic acid, one of the intermediates of heme biosynthesis, increases significantly. Determination of delta-aminolevulinic acid content in biological objects (blood, urine) has clinical and diagnostic value in animal poisoning by heavy metal compounds (Mordarski et al., 2018). The study of the effect of lead ions on the state of porphyrin metabolism will provide additional information about the toxicodynamics of the metal in the body of productive birds in a chronic experiment (Sobhakumari et al., 2019).

The quantitative content of lead in the blood reflects the level of load on the body with its compounds, and the distribution of lead in the organs and tissues of animals depends on the intensity of blood circulation and affinity for metal (Kim et al., 2019; Wang et al., 2021). The results of our studies confirm that the determination of delta-aminolevulinic acid in the serum of poultry is necessary for the timely detection and correction of metabolic disorders caused by low doses of xenobiotics. We have found a dose-dependent effect of lead acetate on the content of delta-aminolevulinic acid in the serum of poultry of the experimental groups. A direct positive correlation has been found between the content of lead and the concentration of delta-aminolevulinic acid in the serum of laying hens that received lead acetate with feed for 120 days. We attribute these changes to the inclusion of lead in heme biosynthesis, resulting in the inhibition of the activity of the enzyme 5 aminolevulinate dehydratase, which catalyzes the formation of porphobilinogen from two molecules of $\delta$ ALA. However, the authors state that disruption of heme synthesis is largely due to the ability of lead ions to form strong covalent bonds with sulfhydryl, carboxyl and amine groups in the active centers of many enzymes of porphyrin metabolism and inhibition of their activity (White, 1975).

According to the authors (Ebrahimi et al., 2015), the cytotoxic effect of the metal in poultry is due to interrelated mechanisms: disruption of calcium homeostasis of cells, inhibition of mitochondrial respiration and increased intensity of lipid peroxidation. Studies by leading scientists have shown that in animals, the metabolism of lead is associated with the metabolism of macronutrients, as the metal is able to enter into various types of interactions (competition, synergism), as well as cause renal dysfunction, which regulates mineral metabolism (De Francisco et al., 2003; Jin et al., 2016). In the conditions of chronic experiment the influence of low doses of lead acetate on a fragment of mineral metabolism in an organism of laying hens has been investigated. It should be noted that in laying hens of highly productive crosses the exchange of calcium and phosphorus is quite intense, which is confirmed by the dynamics of changes in its various forms in the pre- and productive periods ( $\mathrm{Li}$ et al., 2018; Reyer et al., 2021). Calcium is one of the most important mineral elements for laying hens (An et al., 2016). In addition to its main biological functions, which are to form the basis of bone tissue and participate in maintaining the acidalkaline balance of enzymatic systems, in chickens it is the main component of the eggshell. Calcium plays an important role in bone formation, affects muscle contraction, increases the protective functions of the body, reduces the risk of allergies, strengthens blood vessel walls (Attia et al., 2020). Heavy metals compete with calcium in cells because they use its metabolic pathways to enter the body and replace calcium ions in important regulatory blocks. Accumulation of lead in the bones causes a violation of the dissolution of apatite complexes, and as a result calcium is not included in the processes of mineral metabolism, which leads to hypocalcemia. Together with ions of other elements, magnesium is involved in maintaining the ionic balance of body fluids, is part of many enzymes involved in the metabolism of phosphorus and carbohydrates, activates plasma and bone phosphatase and is involved in neuromuscular excitability (Dobrakowski et al., 2017). Inorganic phosphorus is a macronutrient that is involved in many processes and functions of the body: bone formation, energy metabolism, egg shell formation (Boorman \& Gunaratne, 2001). Ferrum is a vital trace element, participates in the functioning of all biological systems, is a mandatory component of proteins and enzymes that provide the necessary level of cellular metabolism and redox homeostasis. Ferrum atoms occupy a central position in hemoglobin molecules (Lin et al., 2020). 
The results of our studies have shown that prolonged administration of lead acetate with feed to poultry caused reliable changes in the content of total calcium, inorganic phosphorus, magnesium and ferrum in the serum of laying hens, which for 120 days received lead acetate in doses of 50,75 and $150 \mathrm{mg} / \mathrm{kg}$ of feed. The nature of these changes can be explained by the ability of lead ions to affect the metabolism of trace elements (Hussain et al., 2020). Studies by scientists confirm that lead and calcium are distributed, deposited and metabolized almost identically. The main danger of lead is not only its accumulation in the bone tissue of animals and humans, but also the replacement of calcium in it, which reduces its density and contributes to the development of osteoporosis.

Thus, based on the results of one-factor analysis of variance and correlation-regression analysis of data, we have established a number of statistical correlations. The analysis of the received data showed that violations of a mineral metabolism in the organism of a productive bird with high probability are caused by chronic influence of lead acetate.

\section{Conclusion}

The biochemical criterion of chronic poisoning of laying hens is deltaaminolevulinic acid. Determination of its content in blood serum has clinical and diagnostic value. The administration of lead acetate into the bodies of productive poultry in doses of 50,75 and $150 \mathrm{mg} / \mathrm{kg}$ with feed for 120 days did not cause visible clinical signs of poisoning, but causes a violation of porphyrin metabolism, manifested in a reliable increase in delta-aminolevulinic acid in serum on the 30th, 90th and 120th days of the experiment. The administration of lead acetate into the body of laying hens in doses of 50,75 and $150 \mathrm{mg} / \mathrm{kg}$ of feed for 120 days led to the maximum accumulation of lead in the serum on the 30th, 90th and 120th days of the experiment. There is a direct positive correlation between the content of lead and the concentration of delta-aminolevulinic acid in the serum of poultry. Prolonged administration of lead acetate to laying hens at doses of 50,75 and $150 \mathrm{mg} / \mathrm{kg}$ of feed on the 30th, 90th and 120th days of the experiment is characterized by a reliable decrease in total calcium, inorganic phosphorus and magnesium in the serum of laying hens and reliable increase in ferrum content.

\section{References}

Adeyemo, O. K., Adedeji, O. B., \& Offor, C. C. (2010). Blood lead level as biomarker of envferrummental lead pollution in feral and cultured African catfish (Clarias gariepinus). Nigerian Veterinary Journal, 31(2), 139-147.

Amin, H., Arain, B. A., Jahangir, T. M., Abbasi, M. S., \& Amin, F. (2018). Accumulation and distribution of lead $(\mathrm{Pb})$ inplant tissues of guar (Cyamopsis tetragonoloba L.) and sesame (Sesamum indicum L.): Profitable phytoremediation with biofuel crops. Geology, Ecology and Landscapes, 2(1), 51-60.

An, S. H., Kim, D. W., \& An, B. K. (2016). Effects of dietary calcium levels on productive performance, eggshell quality and overall calcium status in aged laying hens. Asian-Australasian Journal of Animal Sciences, 29(10), 1477-1482.

Andjelkovic, M., Buha Djordjevic, A., Antonijevic, E., Antonijevic, B., Stanic, M., Kotur-Stevuljevic, J., Spasojevic-Kalimanovska, V., Jovanovic, M., Boricic, N., Wallace, D., \& Bulat, Z. (2019). Toxic effect of acute cadmium and lead exposure in rat blood, liver, and kidney. International Journal of Enviromental Research and Public Health, 16(2), 274.

Assi, M. A., Hezmee, M. N. M., Haron, A. W., Sabri, M. Y., \& Rajion, M. A. (2016). The detrimental effects of lead on human and animal health. Veterinary World, 9(6), 660-671.

Attia, Y. A., Al-Harthi, M. A., \& Abo El-Maaty, H. M. (2020). Calcium and cholecalciferol levels in late-phase laying hens: Effects on productive traits, egg quality, blood biochemistry, and immune responses. Frontiers in Veterinary Science, 7,389 .

Bautista, A. C., Puschner, B., \& Poppenga, R. H. (2014). Lead exposure from backyard chicken eggs: A public health risk? Journal of Medical Toxicology, 10, 311-315.

Boorman, K. N., \& Gunaratne, S. P. (2001). Dietary phosphorus supply, egg-shell deposition and plasma inorganic phosphorus in laying hens. British Poultry Science, 42(1), 81-91.

Boskabady, M., Marefati, N., Farkhondeh, T., Shakeri, F., Farshbaf, A., \& Boskabady, M. H. (2018). The effect of environmental lead exposure on human health and the contribution of inflammatory mechanisms, a review. Environment International, 120, $404-420$.
Choi, H., Ji, S. Y., Jo, H., Song, M., \& Kim, B. G. (2021). Excessive dietary lead reduces growth performance and increases lead accumulation in pigs. Animal Bioscience, 34(1), 102-108.

Clark, J. J., \& Knudsen, A. C. (2013). Extent, characterization, and sources of soil lead contamination in small-urban residential neighborhoods. Journal of Environmental Quality, 42, 1498-1506.

Clemens, S., \& Ma, J. F. (2016). Toxic heavy metal and metalloid accumulation in crop plants and foods. Annual Review of Plant Biology, 67(1), 489-512.

De Francisco, N., Ruiz Troya, J. D., \& Agüera, E. I. (2003). Lead and lead toxicity in domestic and free living birds. Avian Pathology, 32(1), 3-13.

Debnath, B., Singh, W. S., \& Manna, K. (2019). Sources and toxicological effects of lead on human health. Indian Journal of Medical Specialities, 10(2), 66-71.

Dehari-Zeka, M., Letaj, K. R., Selimi, Q. I., \& Elezaj, I. R. (2020). Blood lead level (BLL), $\delta$-aminolevulinic acid dehydratase activity (ALAD), hemoglobin ( $\mathrm{Hb})$ and hematocrit (het) in primary school-children and adult residents living in smelter rural areas in Kosovo. Journal of Environmental Science and Health, 55(10), 1179-1187.

Dobrakowski, M., Boroń, M., Birkner, E., Kasperczyk, A., Chwalińska, E., Lisowska, G., \& Kasperczyk, S. (2017). The effect of a short-term exposure to lead on the levels of essential metal ions, selected proteins related to them, and oxidative stress parameters in humans. Oxidative Medicine and Cellular Longevity, 2017, 8763793.

Ebrahimi, R., Jahromi, M. F., Liang, J. B., Farjam, A. S., Shokryazdan, P., \& Idrus, Z. (2015). Effect of dietary lead on intestinal nutrient transporters mRNA expression in broiler chickens. BioMed Research International, 2015, 149745.

Fillion, M., Blais, J. M., Yumvihoze, E., Nakajima, M., Workman, P., Osborne, G., \& Chan, H. M. (2014). Identification of envferrummental sources of lead exposure in Nunavut (Canada) using stable isotope analyses. Environment International, 71, 63-73.

Hussain, S., Ali, S., Mumtaz, S., Shakir, H. A., Ahmad, F., Tahir, H. M., Ulhaq, M., Khan, M. A., \& Zahid, M. T. (2020). Dose and duration-dependent toxicological evaluation of lead acetate in chicks. Environmental Science and Pollution Research, 27(13), 15149-15164.

Ibrahim, N. M., Eweis, E. A., El-Beltagi, H. S., \& Abdel-Mobdy, Y. E. (2012). Effect of lead acetate toxicity on experimental male albino rat. Asian Pacific Journal of Tropical Biomedicine, 2(1), 41-46.

Jadoon, S., \& Malik, A. (2017). DNA damage by heavy metals in animals and human beings: An overview. Biochemical Pharmacology, 6(3), 1000235.

Jin, X., Liu, C. P., Teng, X. H., \& Fu, J. (2016). Effects of dietary selenium against lead toxicity are related to the ion profile in chicken muscle. Biological Trace Element Research, 172(2), 496-503.

Kim, E., Wickramasuriya, S. S., Shin, T. K., Cho, H. M., Macelline, S. P., Lee, S. D., Jung, J. H., \& Heo, J. M. (2019). Bioaccumulation and toxicity studies of lead and mercury in laying hens: Effects on laying performance, blood metabolites, egg quality and organ parameters. The Journal of Poultry Science, 56(4), 277-284.

Kopic, S., \& Geibel, J. P. (2013). Gastric acid, calcium absorption, and their impact on bone health. Physiological Reviews, 93, 189-268.

Kozak, V. M., \& Brygadyrenko, V. V. (2018). Impact of cadmium and lead on $\mathrm{Me}$ gaphyllum kievense (Diplopoda, Julidae) in a laboratory experiment. Biosystems Diversity, 26(2), 128-131.

Li, P., Wang, R., Jiao, H., Wang, X., Zhao, J., \& Lin, H. (2018). Effects of dietary phosphorus level on the expression of calcium and phosphorus transporters in laying hens. Frontiers in Physiology, 9, 627.

Lin, X., Gou, Z., Wang, Y., Li, L., Fan, Q., Ding, F., Zheng, C., \& Jiang, S. (2020). Effects of dietary ferrum level on growth performance, immune organ indices and meat quality in chinese yellow broilers. Animals, 10(4), 670 .

Manghat, P., Sodi, R., \& Swaminathan, R. (2014). Phosphate homeostasis and disorders. Annals of Clinical Biochemistry, 51(6), 631-656.

Mordarski, D. C., Leibler, J. H., Talmadge, C. C., Wolfus, G. M., Pokras, M. A., \& Rosenbaum, M. H. (2018). Subclinical lead exposure among backyard chicken flocks in Massachusetts. Journal of Avian Medicine and Surgery, 32(3), 185-193.

Oladipo, O. O., Akanbi, O. B., Ekong, P. S., Uchendu, C., \& Ajani, O. (2020). Lead toxicoses in free-range chickens in artisanal gold-mining communities, Zamfara, Nigeria. Journal of Health and Pollution, 10(26), 200606.

Orobchenko, O. L., Roman'ko, M. Y., Paliy, A. P., Dotsenko, R. V., Morozenko, D. V., Gliebova, K. V., Doletskyi, S. P., \& Palii, A. P. (2020). Evaluation of Ag, $\mathrm{Cu}, \mathrm{Fe}$ and $\mathrm{MnO}_{2}$ nanoparticle mixture effecton histomorphological state of internal organs and tissues in laying hens of laying hens. Ukrainian Journal of Ecology, 10(4), 165-174.

Pourrut, B., Shahid, M., Dumat, C., Winterton, P., \& Pinelli, E. (2011). Lead uptake, toxicity, and detoxification in plants. Reviews of Environmental Contamination and Toxicology, 213, 113-136.

Puschenreiter, M., Horak, O., Friesl, W., \& Hartl, W. (2005). Low-cost agricultural measures to reduce heavy metal transfer into the food chain - a review. Plant, Soil and Environment, 51(1), 1-11.

Rădulescu, A., \& Lundgren, S. (2019). A pharmacokinetic model of lead absorption and calcium competitive dynamics. Scientific Reports, 9, 14225. 
Ray, R. R. (2016). Haemotoxic effect of lead: A review. Proceedings of the Zoological Society, 69, 161-172.

Reyer, H., Oster, M., Ponsuksili, S., Trakooljul, N., Omotoso, A. O., Iqbal, M. A., Muráni, E., Sommerfeld, V., Rodehutscord, M., \& Wimmers, K. (2021). Transcriptional responses in jejunum of two layer chicken strains following variations in dietary calcium and phosphorus levels. BMC Genomics, 22(1), 485.

Rodionova, K. O., Nigmatova, O. S., Khimych, M. S., Steshenko, V. M., Broshkov, M. M., Paliy, A. P., Yatsenko, I. V., \& Palii, A. P. (2020). Comparative and legal analysis of the legislation of Ukraine and the European Union in the field of organic production of livestock. Ukrainian Journal of Ecology, 10(6), 280-290.

Roegner, A., Giannitti, F., Woods, L. W., Mete, A., \& Puschner, B. (2013). Public health implications of lead poisoning in backyard chickens and cattle: Four cases. Veterinary Medicine: Research and Reports, 4, 11-20.

Rucińska-Sobkowiak, R. (2016). Water relations in plants subjected to heavy metal stresses. Acta Physiologiae Plantarum, 38, 257.

Sakai, T. (2000). Biomarkers of lead exposure. Industrial Health, 38, 127-142.

Shulman, M. V., Pakhomov, O. Y., \& Brygadyrenko, V. V. (2017). Effect of lead and cadmium ions upon the pupariation and morphological changes in Calliphora vicina (Diptera, Calliphoridae). Folia Oecologica, 44(1), 28-37.

Silva-Sánchez, N., Schofield, J. E., Mighall, T. M., Martínez Cortizas, A., Edwards, K. J., \& Foster, I. (2015). Climate changes, lead pollution and soil erosion in south Greenland over the past 700 years. Quaternary Research, 84(2), 159-173.

Simmonds, R. C. (2017). Chapter 4. Bioethics and animal use in programs of research, teaching, and testing. In: Weichbrod, R. H., Thompson, G. A. H., \& Norton, J. N. (Eds.). Management of animal care and use programs in research, education, and testing. 2nd edition. CRC Press, Taylor \& Francis, Boca Raton. Pp. 1-28.
Sobhakumari, A., Hargrave, S. A., Hill, A. E., \& Poppenga, R. H. (2019). Lead contamination in backyard chicken layer flocks in California. Journal of Veterinary Diagnostic Investigation, 31(3), 359-363.

Soumaoro, I., Pitala, W., Gnandi, K., \& Kokou, T. (2021). Health risk assessment of heavy metal accumulation in broiler chickens and heavy metal removal in drinking water using Moringa oleifera seeds in Lomé, Togo. Journal of Health \& Pollution, 11(31), 210911.

Souri, M. K., Hatamian, M., \& Tesfamariam, T. (2019). Plant grows stage influences heavy metal accumulation in leafy vegetables of garden cress and sweet basil. Chemical and Biological Technologies in Agriculture, 6(25), 2019.

Tangahu, B. V., Abdullah, S. R. S., Basri, H., Idris, M., Anuar, N., \& Mukhlisin, M. (2011). A review on heavy metals $(\mathrm{As}, \mathrm{Pb}$, and $\mathrm{Hg}$ ) uptake by plants through phytoremediation. International Journal of Chemical Engineering, 2011, 939161.

Vorvolakos, T., Arseniou, S., \& Samakouri, M. (2016). There is no safe threshold for lead exposure: A literature review. Psychiatriki, 27(3), 204-214.

Wang, S., Li, Q., Gao, Y., Zhou, Z., \& Li, Z. (2021). Influences of lead exposure on its accumulation in organs, meat, eggs and bone during laying period of hens. Poultry Science, $100(8), 101249$.

Wani, A. L., Ara, A., \& Usmani, J. A. (2015). Lead toxicity: A review. Interdisciplinary Toxicology, 8(2), 55-64.

Warne, R. W., Proudfoot, G. A., \& Crespi, E. J. (2015). Biomarkers of animal health: Integrating nutritional ecology, endocrine ecophysiology, ecoimmunology, and geospatial ecology. Ecology and Evolution, 5(3), 557-566.

White, J. M. (1975). Lead and haemoglobin synthesis: A review. Postgraduate Medical Journal, 51(601), 755-756.

Zaitsev, S. Y., Bogolyubova, N. V., Zhang, X., \& Brenig, B. (2020). Biochemical parameters, dynamic tensiometry and circulating nucleic acids for cattle blood analysis: A review. PeerJ, 8, e8997. 